\title{
The Quality of High Pressure-Induced and Heat-Induced Hyuganatsu Marmalade
}

\author{
Hiroko Kuwada ${ }^{1}$, Yuri Jibu ${ }^{2}$, Mayumi Tabuchi ${ }^{2}$, Ai Teramoto ${ }^{3}$, Kayoko Ishii ${ }^{1}$ and Michiko Fuchigami ${ }^{1}$ \\ 1. Department of Nutrition and Life Science, Fukuyama University, Fukuyama, Hirosima-ken 729-0292, Japan \\ 2. Department of Nutritional Science, Okayama Prefectural University, Soja, Okayama-ken 719-1197, Japan \\ 3. Department of Health and Nutrition, Kanto Gakuin University, Yokohama, Kanagawa-ken 236-8501, Japan
}

Received: November 4, 2013 / Published: December 20, 2013.

\begin{abstract}
Hyuganatsu is a typical Japanese citrus with desirous smell and edible albedo. The objectives of this study are to establish a method for softening hyuganatsu peel without heating and a process for making a high pressure-induced (HP-) marmalade and to compare with heat-induced (H-) marmalade and citrus shaddock family marmalade. Firmness of peel was (greatest to least) pressurized at $500 \mathrm{MPa}$ for $30 \mathrm{~min}$, soaked in citric acid solution at $\mathrm{pH} 2.7$ for $24 \mathrm{~h}$, and boiled for $10 \mathrm{~min}$, respectively. The cell walls of flavedo and albedo did not loosen after pressurization. However, after soaking or heating, the middle lamella of albedo separated. When flavedo was soaked at $\mathrm{pH} 2.7,9.3 \%$ of pectin was extracted. The amount of naringin was the least in hyuganatsu $<$ pummelo $<$ grapefruit), and juice sacs $<$ flavedo $\leq$ segment walls $<$ albedo, respectively. Thus, marmalade was processed. Albedo, segment walls and juice sacs of hyuganatsu were homogenized with citric acid solution ( $\mathrm{pH}$ 2.7) and mixed with sliced flavedo. Then it was soaked for $24 \mathrm{~h}$ at $\mathrm{pH}$ 2.7. Sucrose was then added (final sugar 50\%), vacuum packed, then pressurized for $30 \mathrm{~min}$ at $500 \mathrm{MPa}$ or boiled for $10 \mathrm{~min}$, respectively. There was no significant difference in sensory evaluation between HP- and H-marmalade. However, the color, transparency and total evaluation of HP-marmalade were better than H-marmalade. Consequently, total evaluation of hyuganatsu-HP-marmalade was rated highly. So, hyuganatsu was considered to be more suitable for marmalade because it was more palatable than the others.
\end{abstract}

Key words: Hyuganatsu, pectin, high pressure, processing, marmalade, texture, structure.

\section{Introduction}

In Japan, many kinds of citrus fruit that may be relatively unknown in other countries are cultivated and have a unique flavor. Among them, hyuganatsu (Citrus tamurana Hort. ex Tanaka), locally named konatsu (in Kochi prefecture) or new summer orange (in Shizuoka and Ehime prefectures), has been regarded as a citrus fruit with potential commercial value. The name comes from Hyuga, the ancient name of Miyazaki prefecture in Kyushu where it originated. "Natsu" means summer. Hyuganatsu was found in Miyazaki city in the 1820 s, after which it became widely cultivated throughout the region. It is thought to

Corresponding author: Hiroko Kuwada, research assistant, research field: cookery science. E-mail: kuwada@fubac.fukuyama-u.ac.jp. be either a mutated yuzu or perhaps more likely a chance hybrid between yuzu and pummelo. This fruit is mainly grown in Japan's Miyazaki and Kochi prefectures. Most citrus fruit in Japan is usually harvested by the end of the year in order to avoid chilling injuries and maintain its commercial quality. Hyuganatsu fruit is however, commonly left on the trees until the following spring because of its resistance to winter's severe cold [1]. Thus, hyuganatsu is popular in Japan from early spring to summer.

Hyuganatsu has a light yellow color and round shape with a diameter of 8-10 cm and a weight of 180-200 g. It has a pleasant aroma, a sweet and a slightly sour taste, and is juicy. The white pith (albedo) between the flesh and peel is very thick but not bitter and is eaten together with the flesh. Thus, citrus hyuganatsu is 
desirable because of its flavor, taste and nutrients. Its oil is higher in trans- $\beta$-farnesene, 1 -carvone than other citrus fruits, and has a higher number of ketones [1]. The taste is very fragrant.

High pressure processing is a new method of avoiding off-flavor and thus attracted the attention of the food industry in Japan [2]. Therefore, high pressure-induced (HP-) food products such as jam, fruit sauce, juice, uncooked ham, rice cakes containing herbs (yomogi mochi) and cooked at-high-pressure processed rice have since been marketed in Japan. High pressure is able to produce jam without heating [3], because pressurization accelerates hydrogen bonds between pectin molecules [2]. Heat-induced (H-) jam and marmalade (products by conventional thermal treatment) have some faults such as off-flavor and deterioration of nutrients and especially color. However, high pressure is able to produce jam without heating. Thus, HP-jam was patented by Meidi-ya Ltd. in Japan in 1990 [4], and pressure-induced jam, such as strawberries, blue berries and apples have since been marketed using this method. However, pectin is added to this pressure-induced jam. Citrus possesses sufficient pectin and acid to form jelly/marmalade. Therefore, a new method for forming jelly without the addition of pectin was investigated using citrus yuzu.

When high methoxyl pectin is extracted by soaking in $0.01 \mathrm{~N} \mathrm{HCl}$ solution $(\mathrm{pH} 2.0)$ at $35{ }^{\circ} \mathrm{C}$, vegetables are softened due to the removal of $\mathrm{Ca}^{2+}$ [5-7]. This extraction method of pectin [5-7] was used for softening the peel of yuzu by using citric acid instead of $\mathrm{HCl}$. However, yuzu marmalade which was processed after soaking at $\mathrm{pH} 2.0$ was slightly sour, especially more sour in yuzu marmalade with $50 \%$ sucrose than that with $60 \%$ sucrose [8]. Therefore, yuzu was soaked in $0.06 \%$ citric acid solution ( $\mathrm{pH} 2.7$ ), then yuzu marmalade with $50 \%$ sucrose was processed [9]. When soaked at $\mathrm{pH} 2.7$, flavedo did not become softer than when it was soaked at pH 2.0 [10]. Yuzu marmalade was made [9], because the optimum $\mathrm{pH}$ value for most standard preserves and jellies is in the range of 2.6-3.4. Too much acid causes excessive syneresis, while too little acid (resulting in $\mathrm{pH}$ values which are too high) impairs proper jellification or prevents setting of altogether [11]. Thus, $\mathrm{pH} 2.7$ is more suitable for the gelation of pectin (jelly-forming) and gives a more desirous viscosity for marmalade.

Thus, this process is applicable in citrus hyuganatsu which is one of the citrus shaddock families. In this paper, hyuganatsu will be soaked in $0.06 \%$ citric acid solution ( $\mathrm{pH}$ 2.7), then hyuganatsu marmalade with $50 \%$ sucrose will be processed. Hyuganatsu will be compared with pummelo and grapefruit which are also citrus shaddock families. Then it will be judged that whether hyuganatsu is suitable for HP-marmalade or not.

The objectives of this study are to establish a method for softening hyuganatsu peel without heating and a process for making a HP-marmalade to compare with H-marmalade and other kinds of citrus shaddock family marmalade.

\section{Materials and Methods}

\subsection{Sample Preparation}

Marketed hyuganatsu (Citrus tamurana Hort. ex Tanaka, cultivated in Kochi, Japan, obtained in May), pummelo (Citrus grandis Osbeck, cultivated in Kochi, Japan, obtained in April) and grapefruit (Citrus paradisi Macf, imported from California, USA, obtained in June) were used for the experiment and shown in Figs. 1a-1c. The surface of the peel is called flavedo (an epicarp) and is yellow. The inside of flavedo is called albedo (a mesocarp). It is white and spongy. An endocarp consists of several segments of juice sacs which are surrounded by a segment wall [9]. Hyuganatsu, pummelo and grapefruit were divided into flavedo, albedo, segment walls and juice sacs, respectively, with weight percentages shown in Figs. 1d-1f.

The schematic flowchart for processing marmalade is shown in Fig. 2. For processing marmalade, half of hyuganatsu (Fig. 1a), a quarter of pummelo (Fig. 1b) 


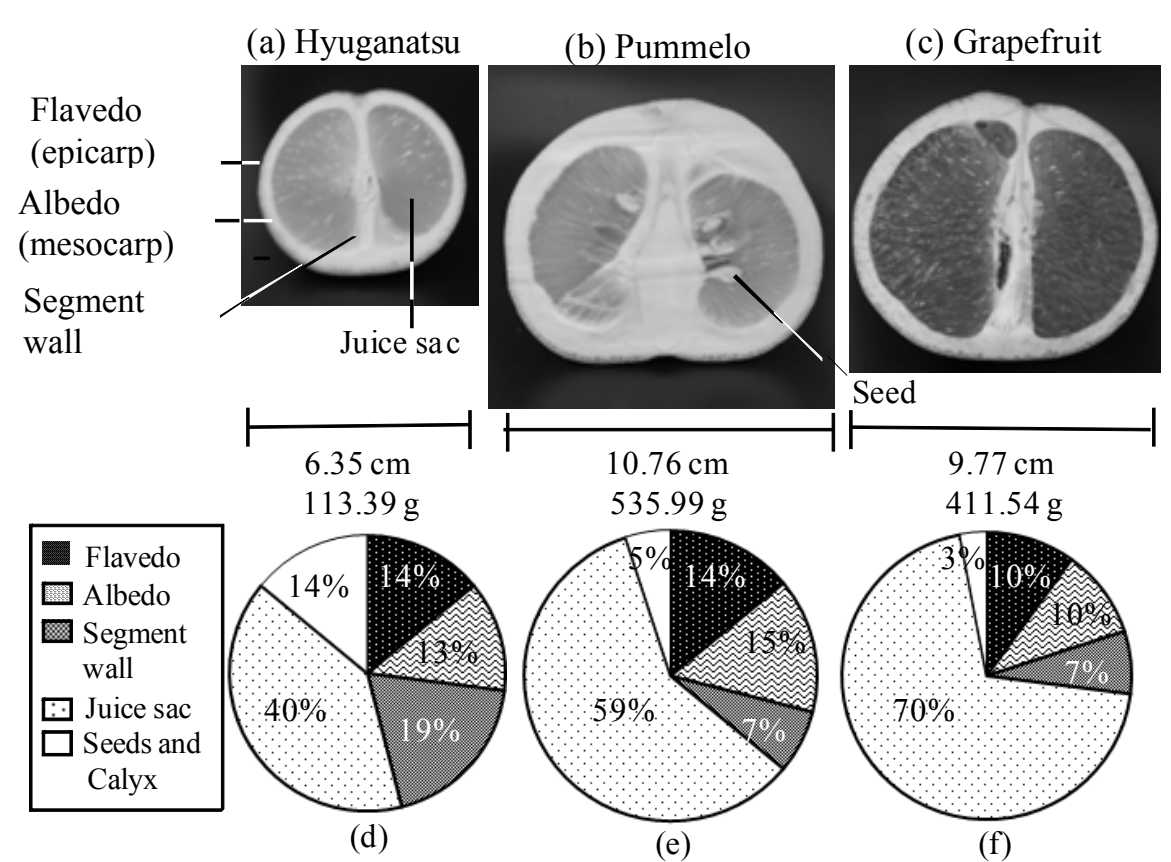

Fig. 1 The structure and weight percentage of flavedo, albedo, segment walls and juice sacs of hyuganatsu, pummelo and grapefruit.

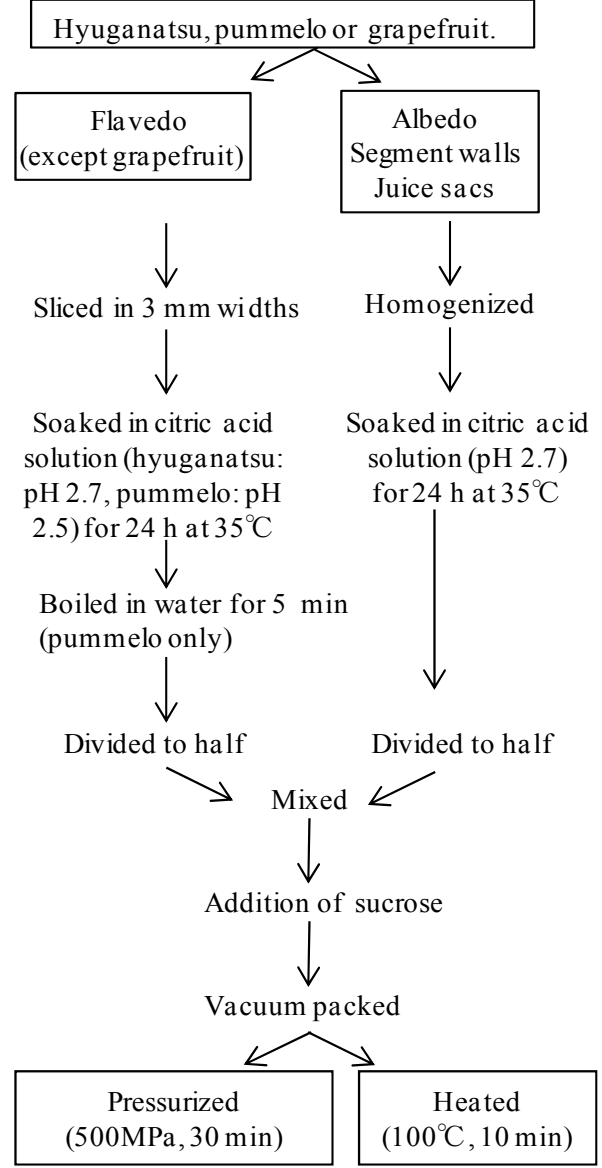

Fig. 2 The schematic flowchart for the processing of marmalades. and a quarter of grapefruit (Fig. 1c) were used for one experiment, respectively. Flavedo was sliced in $3 \mathrm{~mm}$ widths. Flavedo of hyuganatsu (8.06 g) was soaked in $0.06 \%$ citric acid solution $(\mathrm{pH} 2.7,16.12 \mathrm{~g}$ ) for $24 \mathrm{~h}$ at $35{ }^{\circ} \mathrm{C}$. That of pummelo $(19.26 \mathrm{~g})$ was soaked in $0.3 \%$ citric acid solution ( $\mathrm{pH} 2.5,38.52 \mathrm{~g}$ ) for $24 \mathrm{~h}$ at $35^{\circ} \mathrm{C}$, then boiled in water for $5 \mathrm{~min}$, because it was very hard. Flavedo of grapefruit was not used, because it was very bitter.

Albedo, segment walls and juice sacs (hyuganatsu: 7.15, 10.78 and 22.99 g; pummelo: 20.45, 9.11 and $78.02 \mathrm{~g}$; grapefruit: $10.52,7.42$ and $71.50 \mathrm{~g}$, respectively) were homogenized with $0.06 \%$ citric acid solution ( $\mathrm{pH} 2.7$, half amount of albedo, segment walls and juice sacs: $20.46 \mathrm{~g}$ for hyuganatsu; $53.79 \mathrm{~g}$ for pummelo; $44.72 \mathrm{~g}$ for grapefruit), and adjusted to $\mathrm{pH}$ 2.7 using citric acid, then they were soaked for $24 \mathrm{~h}$ at $35{ }^{\circ} \mathrm{C}$. They were mixed with flavedo then sucrose (Nacalai Tesque, Inc., Kyoto) was added (final sugar $50 \%$ ). However, sugar content of the juice was subtracted from the added sucrose content. The sugar content (brix) of juice and the hyuganatsu marmalade were measured by a digital refractometer (PR-100 or 
PR-200, Atago Ltd., Tokyo).

The samples were then vacuum packed, and pressurized for $30 \mathrm{~min}$ at $500 \mathrm{MPa}$ at room temperature (about $20{ }^{\circ} \mathrm{C}$ ) using a Dr. Chef high pressure food processor (Kobe Steel Ltd., Kobe, Japan) or boiled in hot water $(850 \mathrm{~mL})$ for $10 \mathrm{~min}$, respectively.

\subsection{Texture Measurement of Flavedo (Hyuganatsu)}

Changes in texture of hyuganatsu samples during soaking, pressurizing or heating, and texture of HP- or H-marmalade were measured by a creepmeter (Rheoner, RE-33005, Yamaden Ltd., Tokyo, Japan). The yellow surface of the flavedo was punctured at 1 $\mathrm{mm} / \mathrm{s}$ by a plunger (cylindrical shape: $2 \mathrm{~mm}$ diameter, $22 \mathrm{~mm}$ long) using a loadcell of $2 \mathrm{~kg}$. The rupture stress and rupture strain (the mean of 10 measurements) were indicated.

\subsection{Structure Measurement of Peel (Hyuganatsu)}

The minute structures of the hyuganatsu samples (flavedo and albedo) were observed using a cryo-scanning electron microscope (S-4500, Hitachi Ltd., Tokyo, Japan). Samples were cut and dehydrated with $40 \%$ and $50 \%$ ethanol. The specimen was contained in a metal holder and quickly frozen by immersing in liquid nitrogen $\left(\mathrm{LN}_{2}\right)$. The frozen specimen was transferred to a cold stage of the cryo-system for scanning electron microscopy and cut with a knife $\left(-150{ }^{\circ} \mathrm{C}\right)$. After etching at $-85{ }^{\circ} \mathrm{C}$, the surface was coated with gold then observed at $-120{ }^{\circ} \mathrm{C}$ under low acceleration voltage $(1 \mathrm{kV})$.

\subsection{Extraction and Determination of Pectin from Four} Parts of Hyuganatsu

The raw and soaked samples were cut into tiny pieces, then 99.5\% ethanol (four times amount of sample) was added. This was homogenized three times for 2 min using an excel-auto homogenizer (EO-9, Nihon-Seiki, Tokyo) then poured into a weighted glass-filter (3G2). It was washed successively using $80 \%$ ethanol until there was no sugar-reaction by the phenol-sulfuric acid method [12], 90\% ethanol and acetone, then dried at $20{ }^{\circ} \mathrm{C}$. The alcohol-insoluble-solids (AIS) were prepared by this method.

Pectic substances from AIS were extracted into three reagents, successively: solutions were distilled water (at $20{ }^{\circ} \mathrm{C}, 12 \mathrm{~h} \times 2$ ), $0.4 \%$ sodium hexametaphosphate solution (at $20^{\circ} \mathrm{C}, 2 \mathrm{~h} \times 2$ ) and $0.05 \mathrm{~N} \mathrm{HCl}$ solution (at $\left.85^{\circ} \mathrm{C}, 1 \mathrm{~h}\right)$ [14]. These fractions were designated as water-soluble pectin (WSP), sodium hexametaphosphate-soluble pectin (PSP) and $\mathrm{HCl}$-soluble pectin (HSP), respectively. The amount of galacturonic acid in these fractions was determined by the carbazole method [15].

\subsection{Color Measurement of Flavedo}

The color (L-, a- and b-values) of flavedo of hyuganatsu (raw, soaked at $\mathrm{pH} 2.7$ for $24 \mathrm{~h}$, pressurized at $500 \mathrm{MPa}$ for $30 \mathrm{~min}$ or heated for $10 \mathrm{~min}$ ) and color of flavedo and jelly (without flavedo) in HP- or H-marmalade were measured by using a spectrophotometer ZE-6000 (NDK, Osaka, Japan).

\subsection{Rheology Measurement of Marmalade}

The steady-flow viscosity, thixotropy and dynamic-viscoelasticity of jelly in marmalade (hyuganatsu, pummelo and grapefruit) were measured at $25^{\circ} \mathrm{C}$ by using a Rheosol-G3000 (UBM Ltd., Kyoto, Japan). Steady-flow viscosity of six kinds of marmalades was compared.

2.7 Extraction and Determination of Naringin from Four Parts of the Citrus Shaddock Family and Marmalade

The raw and treated samples (1.0-6.0 g) were cut into tiny pieces, then distilled water $(10 \mathrm{~mL})$ was added. The extracts, by soaking for $3 \mathrm{~min}$, were strained through a glass-filter (3G2). The amount of naringin was determined by the Iwata and Ogata method [16]. The diethylene glycol $(10 \mathrm{~mL})$ and $1 \mathrm{~N} \mathrm{NaOH}(1 \mathrm{~mL})$ were added to the extracts $(1 \mathrm{~mL})$, they were incubated 
for $30 \mathrm{~min}$ at $30{ }^{\circ} \mathrm{C}$, then the absorbances at $420 \mathrm{~nm}$ were determined.

\subsection{Sensory Evaluation of Marmalades}

Sensory evaluation of hyuganatsu marmalades was performed using a five point scale ( -2 to 2 ). The color (bad to excellent), transparency (opaque to transparent), flavor (smell) of fruit (weak to strong), mouth feel (rough to smooth), texture of jam (soft to firm, not like to like), sweetness, sourness and bitterness (weak to strong, not like to like), and total evaluation (bad to excellent) were all compared. Samples were evaluated by 25 students and teachers (20-64 years old).

\section{Results and Discussion}

3.1 The Weight Percentage of Flavedo, Albedo, Segment Walls and Juice Sacs

The structure and weight percentage of flavedo, albedo, segment walls and juice sacs of hyuganatsu, pummelo and grapefruit are shown in Figs. 1a-1c and Figs. 1d-1f, respectively. The weight of a fruit, sugar content in juice and the $\mathrm{pH}$ value of juice were as follows: hyuganatsu (113 $\pm 4 \mathrm{~g}, 14.7 \% \pm 0.4 \%$ sugar, pH $3.33 \pm 0.25$ ), pummelo (536 $\pm 43 \mathrm{~g}, 11.5 \% \pm 0.4 \%$ sugar, $\mathrm{pH} 3.37 \pm 0.13)$ and grapefruit $(412 \pm 66 \mathrm{~g}$, $10.4 \%$ sugar, $\mathrm{pH} 3.22$ ), respectively. The size of fruit was (biggest to smallest): pummelo $>$ grapefruit $>$ hyuganatsu. The percentage of juice sacs was (greatest to least): grapefruit $>$ pummelo $>$ hyuganatsu, and that of segment walls + albedo was reversed: hyuganatsu $>$ pummelo $>$ grapefruit.

\subsection{Changes in Texture of Flavedo (Hyuganatsu)} during Soaking, Pressurizing or Heating and Processing Marmalade

Changes in stress-strain curves (Fig. 3a), rupture stress (Fig. 3b) and strain (Fig. 3c) of flavedo (hyuganatsu) during soaking in citric acid solutions, pressurizing or heating, and rupture stress and strain of HP- or H-marmalade are shown in Fig. 3.
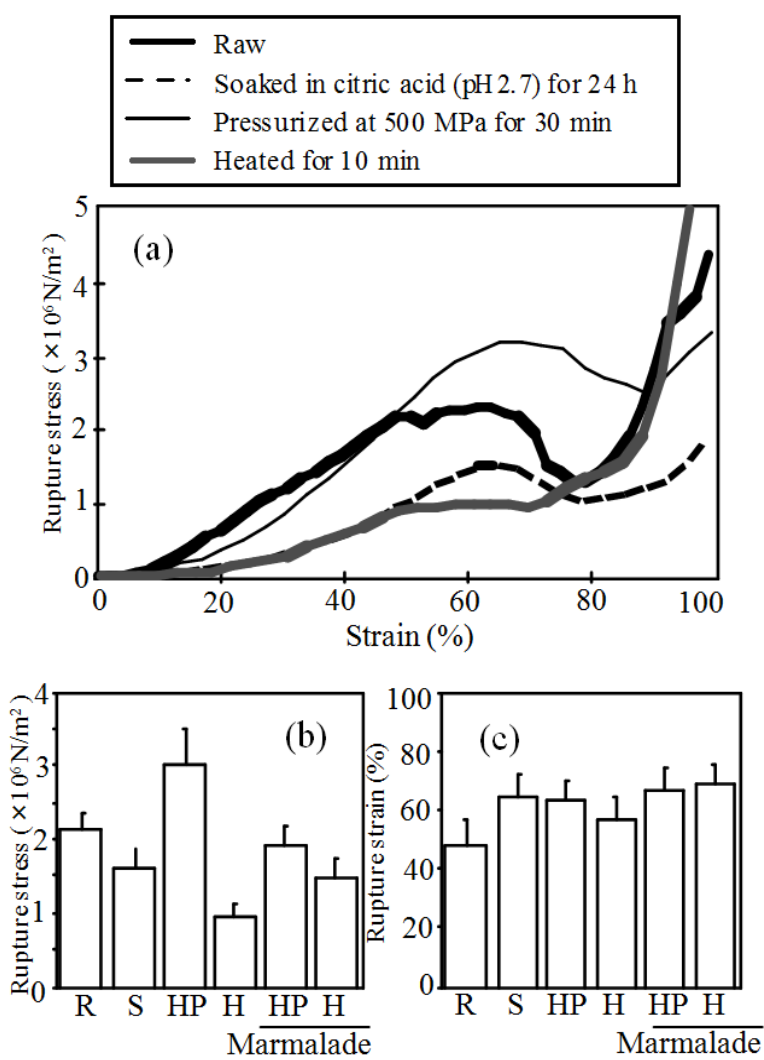

Fig. 3 Typical stress-strain curves, rupture stress and strain of flavedo of hyuganatsu after soaking pressurizing or heating and HP- or H-marmalade.

R: raw; S: soaked in citric acid for $24 \mathrm{~h}$ at $\mathrm{pH} 2.7$; HP: pressurized at $500 \mathrm{MPa}$ for $30 \mathrm{~min}$; $\mathrm{H}$ : heated for $10 \mathrm{~min}$ in boiling water.

The rupture stress of flavedo soaked for $24 \mathrm{~h}$ at $\mathrm{pH}$ 2.7 decreased slightly due to the removal of $\mathrm{Ca}^{2+}$. By pressurization at $500 \mathrm{MPa}$ for $30 \mathrm{~min}$, the rupture stress of flavedo increased, since pectin does not degrade through trans-elimination by pressurization. Heated flavedo became softer than raw flavedo. Heating at above $\mathrm{pH} 5$, pectin degrades by trans-elimination [20]. However, the $\mathrm{pH}$ value of flavedo was acidic, thus, pectin might degrade by hydrolysis.

The rupture stress of flavedo in HP-marmalade decreased slightly more than that of raw flavedo. The firmness of flavedo in H-marmalade was softer than HP-marmalade. Heating for $10 \mathrm{~min}$ in a vacuum pack at $\mathrm{pH} 2.7$ might accelerate the degradation of pectin by hydrolysis, consequently flavedo became soft. However, the flavedo in H-marmalade was firmer than heated flavedo. It might be dehydrated probably 
with sucrose.

\subsection{Changes in Structure of Peel (Hyuganatsu) during Soaking, Pressurizing or Heating}

The minute structures of flavedo and albedo of hyuganatsu are shown in Fig. 4. The magnifications used to observe the changes in structures during soaking, pressurizing and heating were $\times 1,000$ (cells, Figs. $4 a_{1}-4 a_{4}$ and Figs. $4 b_{1}-4 b_{4}$ ) and $\times 20,000$ (cell wall, Figs. $4 c_{1}-4 c_{4}$, Figs. $\left.4 d_{1}-4 d_{4}\right)$, respectively. The size of cells of the outer part (surface) of flavedo was smaller than that of the inner part (Figs. $4 \mathrm{a}_{1}-4 \mathrm{a}_{4}$ ). Round cells with thick/thin cell walls were also observed. The structures of albedo became more spongy as the albedo moved inward.

When flavedo and albedo of hyuganatsu were soaked for $24 \mathrm{~h}$ at $\mathrm{pH} 2.7$, both cell walls became loose (Figs. $4 c_{2}$ and $4 d_{2}$ ) and the middle lamella of albedo separated (Fig. $4 \mathrm{~d}_{2}$ ). After heating, the middle lamella of albedo separated (Fig. $4 \mathrm{~d}_{4}$ ) and the cell walls of flavedo became slightly loose (Fig. $4 \mathrm{c}_{4}$ ). However, they did not loosen after pressurization (Figs. $4 c_{3}$ and $\left.4 d_{3}\right)$.

In a previous paper [10], after soaking for $24 \mathrm{~h}$ at $\mathrm{pH}$ 2.7 the cell walls of yuzu flavedo did not loosen, but the albedo became loose. The middle lamella of flavedo of yuzu separated after soaking for $24 \mathrm{~h}$ at $\mathrm{pH} 2.0$, and the cell walls of albedo became loose after $3 \mathrm{~h}$ and melted after $24 \mathrm{~h}$ of soaking at $\mathrm{pH} 2.5$ [10].

\subsection{Changes in Pectin of Hyuganatsu}

Pectic substances in hyuganatsu were extracted into three reagents: WSP, which was extracted in cold water, contained water-soluble pectin and water-soluble pectate; PSP, which was extracted in sodium hexamethaphosphate solution, contained pectinate and
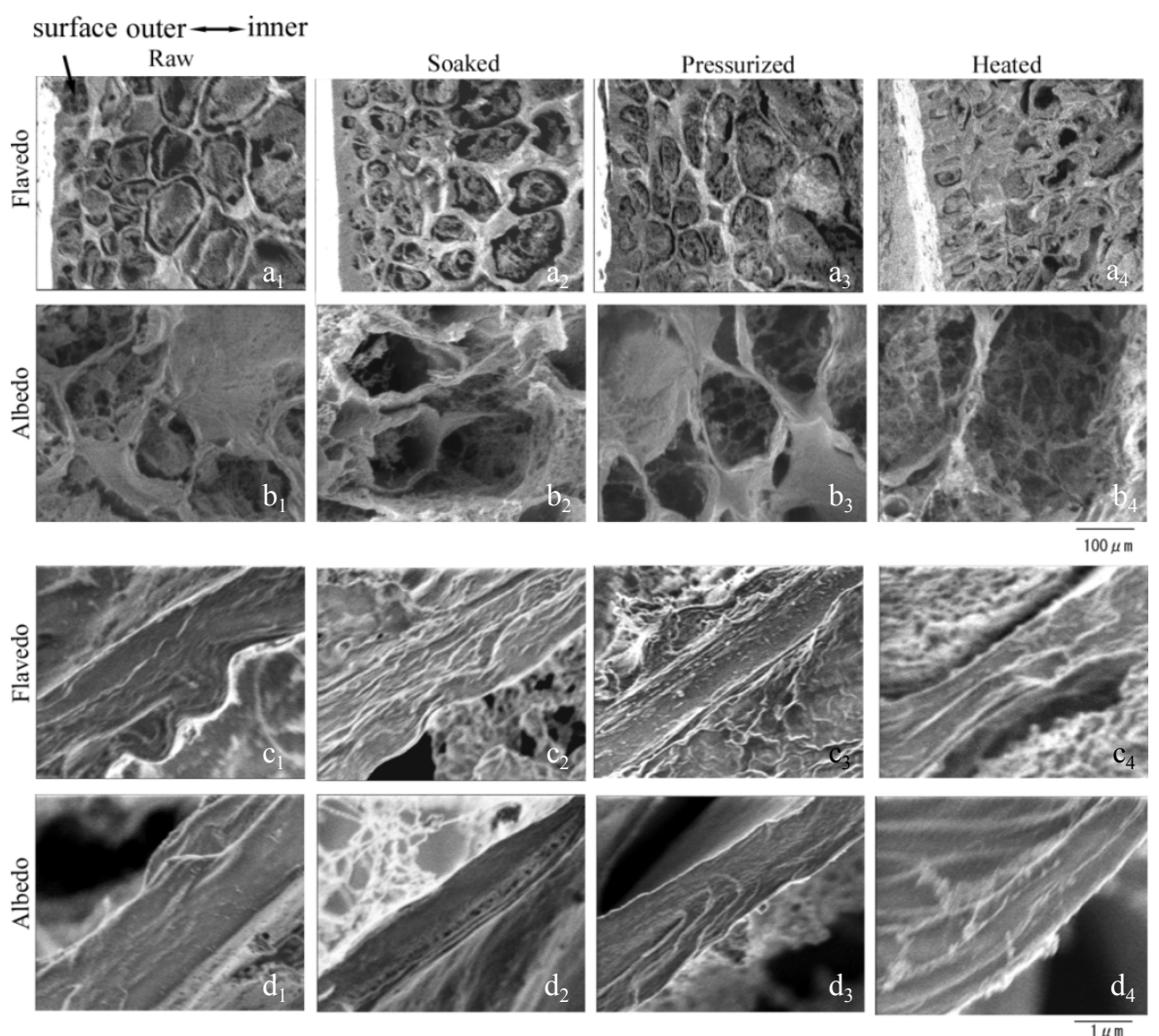

Fig. 4 Changes in cryo-scanning electron micrographs of flavedo and albedo of hyuganatsu during soaking, pressurizing and heating.

Soaked: soaked in citric acid solution for $24 \mathrm{~h}$ at $\mathrm{pH}$ 2.7; pressurized: pressurized at $500 \mathrm{MPa}$ for $30 \mathrm{~min}$; heated: heated for $10 \mathrm{~min}$ in boiling water. 
water-insoluble pectate; HSP, which was extracted in $0.05 \mathrm{~N} \mathrm{HCl}$ solution and was protopectin [14].

Pectin composition of flavedo, albedo, segment walls and juice sacs of raw hyuganatsu and changes in pectin composition of flavedo by soaking in citric acid solution are shown in Fig. 5. The amount of pectin was the greatest in albedo $\geq$ flavedo $\geq$ segment walls $>$ juice sacs, respectively; however, it was almost the same. Conversely, juice sacs contained an extremely small amount of pectin. The amount of pectin in albedo of hyuganatsu was smaller than that of yuzu [14].

The percentage of HSP was greatest in all parts (except juice sacs) compared to PSP $>$ WSP, respectively. The percentage of WSP in hyuganatsu was smaller than that of PSP, HSP and also raw peach fruit [21]. It suggests that hyuganatsu contains a smaller amount of low molecular weight-pectin than peach.

When flavedo of hyuganatsu was soaked in citric acid (pH 2.7) for $24 \mathrm{~h}$, only $9.3 \%$ of pectin was extracted. However, about $30 \%$ pectin of flavedo of yuzu was extracted by soaking for $24 \mathrm{~h}$ at $\mathrm{pH} 2.0$ written in a previous paper $[8,10]$. Also, more pectin was extracted when flavedo was soaked at $\mathrm{pH} 2.0$ rather than at $\mathrm{pH} 2.7$, due to the acceleration of the removal of $\mathrm{Ca}^{2+}[10]$. Thus, rupture stress of hyuganatsu decreased slightly because the $\mathrm{pH}$ value was 2.7 .

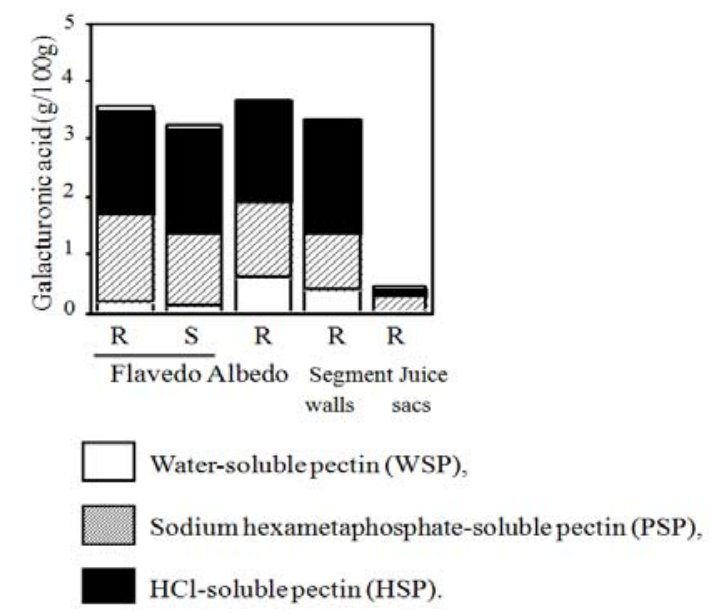

Fig. 5 Pectin composition of raw flavedo, albedo, segment walls and juice sacs of hyuganatsu and changes in pectin composition of flavedo by soaking in citric acid solution. $\mathrm{R}$ : raw; $\mathrm{S}$ : soaked in citric acid for $24 \mathrm{~h}$ at $\mathrm{pH} 2.7$.

\subsection{Changes in Color of Marmalade}

The L-value (+ brightness, Fig. 6a), a-value (+ red, - green, Fig. 6b) and b-value (+ yellow, - blue, Fig. 6c) of flavedo of hyuganatsu during soaking, pressurization or heating and marmalades are shown in Fig. 6. L-, a- and b-values decreased when flavedo was soaked, pressurized or heated and also that of peel and jelly in marmalades decreased. However, L- and b-values of HP-marmalade were higher than that of $\mathrm{H}$-marmalade, and more similar to that of raw flavedo. Thus, peel and jelly of HP-marmalade preserved its natural color.

\subsection{Changes in Rheology of Marmalades}

The steady-flow viscosity of marmalades (citrus shaddock family) is shown in Fig 7. The viscosity was slightly higher in pummelo (Fig. 7b) $>$ hyuganatsu (Fig. 7a) $>$ grapefruit (Fig. 7c), respectively. However, a great difference in viscosity between $\mathrm{HP}-$ and H-marmalade was not found.

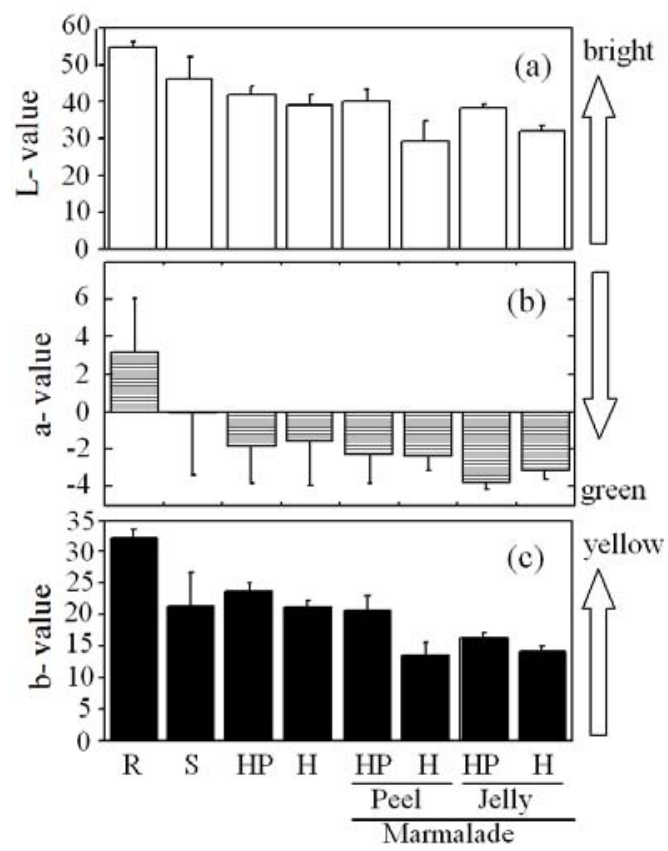

Fig. 6 Changes in L-, a- and b-values of flavedo of hyuganatsu during soaking, pressurization or heating and marmalades.

R: raw; S: soaked in citric acid for $24 \mathrm{~h}$ at $\mathrm{pH} 2.7$; HP: pressurized at $500 \mathrm{MPa}$ for $30 \mathrm{~min}$; $\mathrm{H}$ : heated for $10 \mathrm{~min}$ in boiling water. 


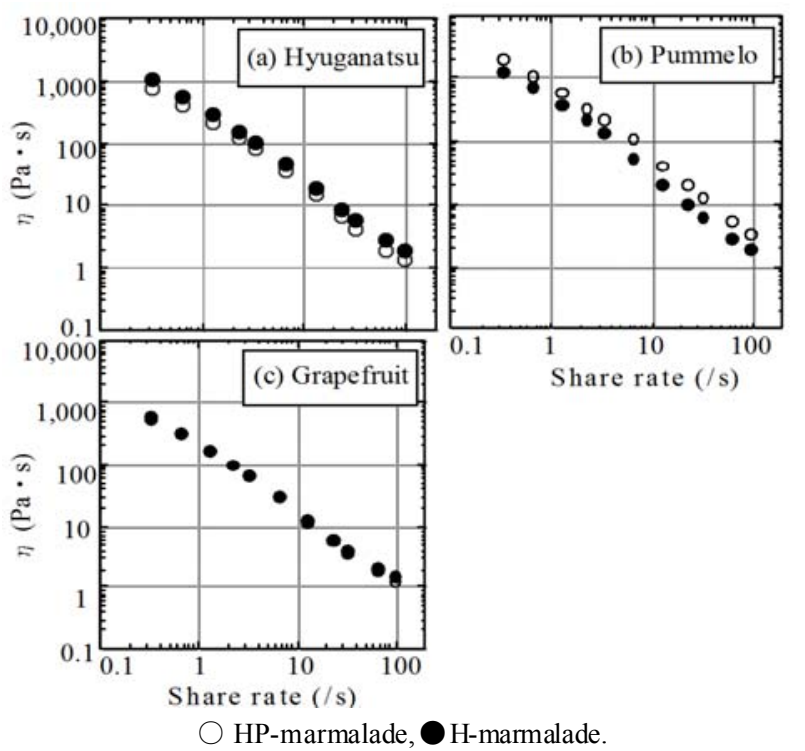

Fig. 7 Steady-flow viscosity of high pressure-induced (HP-) and heat-induced (H-) marmalades.

Since the thixotropy and dynamic-viscoelasticity showed a similar tendency, they are not shown.

\subsection{The Amount of Naringin in Citrus Shaddock Family and Marmalades}

The amount of naringin in the citrus shaddock family and marmalades is shown in Fig. 8. The amount of naringin was the greatest in grapefruit (Fig. 8c) $>$ pummelo (Fig. 8b) > hyuganatsu (Fig. 8a), and albedo $>$ segment walls $\geq$ flavedo $>$ juice sacs, respectively. That of marmalades showed a similar tendency (Figs. $8 \mathrm{~d}$ and $8 \mathrm{e}$ ). The amount of naringin in hyuganatsu was the least. Therefore, Japanese eat hyuganatsu with albedo. Hyuganatsu is suitable for marmalade because it was more palatable than the others.

\subsection{Sensory Evaluation of Marmalades}

Sensory evaluation of hyuganatsu marmalade is shown in Fig. 9. There was no significant difference in sensory evaluation between HP- and H-marmalade. However, the color, transparency and total evaluation of HP-marmalade were comparatively better than H-marmalade. The color was maintained by pressurization. Also, the bitterness of HP-marmalade was weaker than H-marmalade. It was suggested that the bitterness was restrained by pressurization [17]. Flavor (smell) of fruit of HP-marmalade was weaker and texture of the jelly was softer than H-marmalade. However, for a total evaluation, HP-marmalade of hyuganatsu was higher rated (about four points/five points).
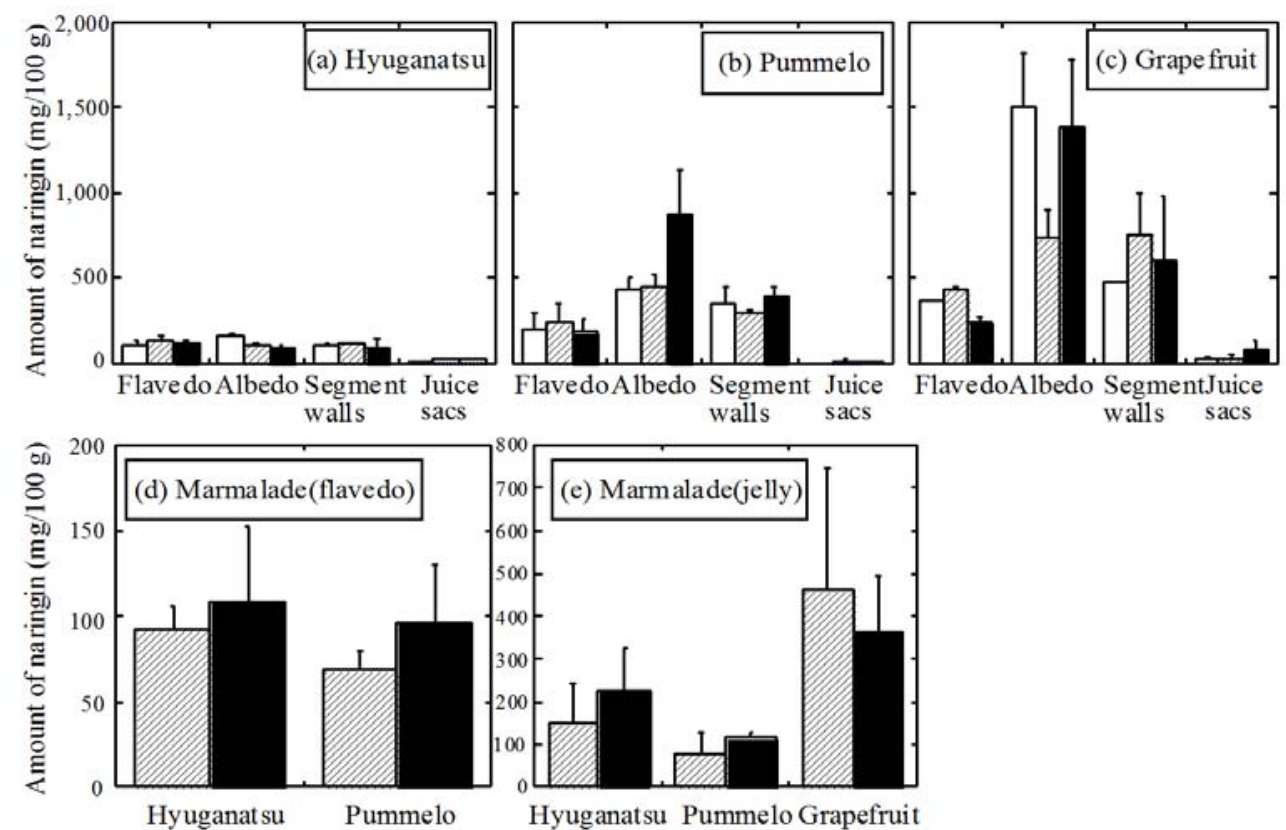

$\square$ Raw, $\square$ Pressurized at $500 \mathrm{MPa}$ for $30 \mathrm{~min}$, Heated for $10 \mathrm{~min}$ in a boiling water.

Fig. 8 The amount of naringin in hyuganatsu, pummelo, grapefruit and marmalades.

Pressurized: pressurized at $500 \mathrm{MPa}$ for $30 \mathrm{~min}$; heated: heated for $10 \mathrm{~min}$ in boiling water. 


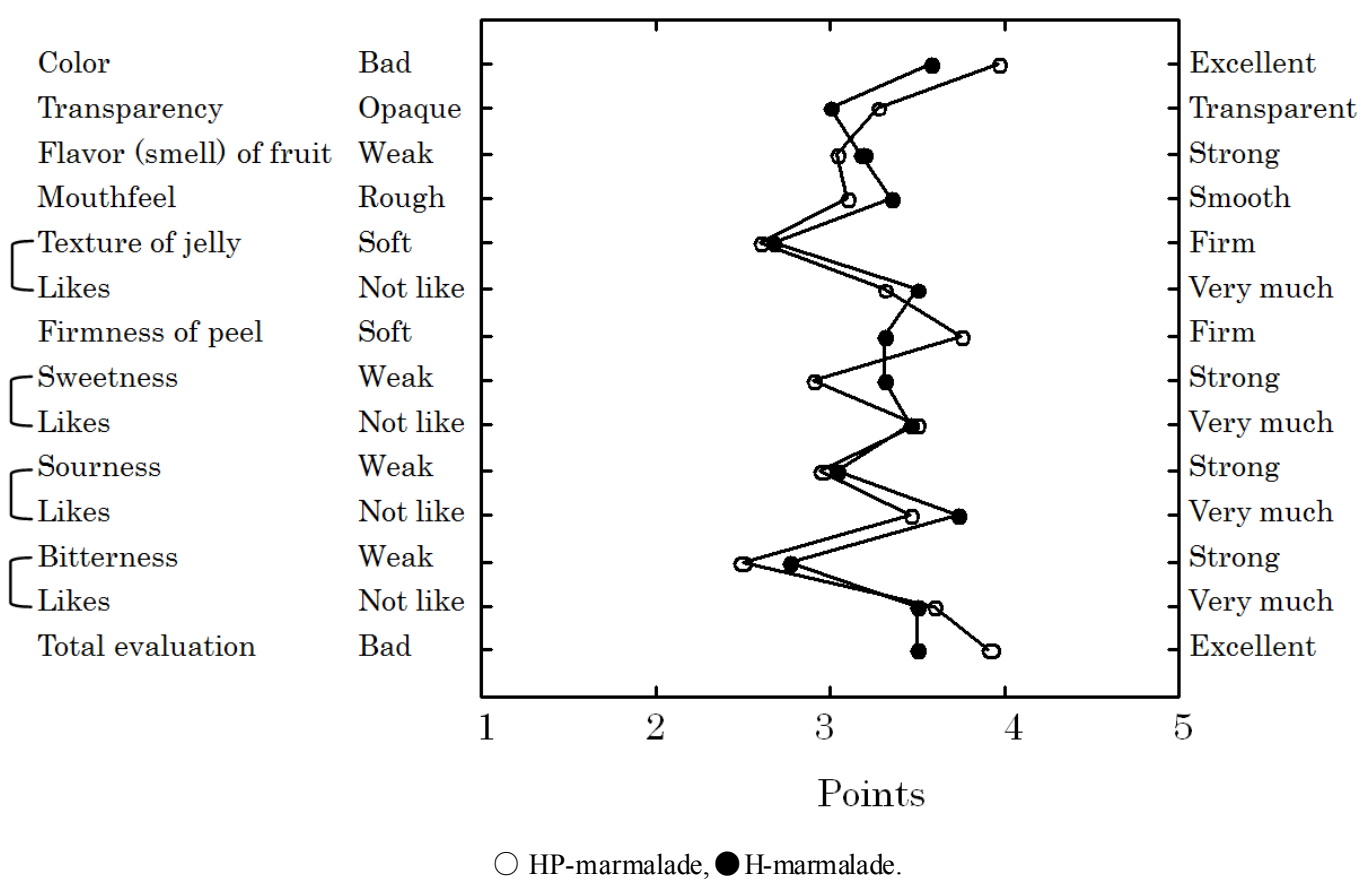

Fig. 9 Sensory evaluation of hyuganatsu marmalade.

\section{Conclusions}

Hyuganatsu is a typical Japanese citrus with desirous smell and edible albedo. Firmness of peel (flavedo) of hyuganatsu was (greatest to least): pressurized for $30 \mathrm{~min}$ at $500 \mathrm{MPa}>$ soaked in citric acid solution for $24 \mathrm{~h}$ at $\mathrm{pH} 2.7>$ boiled for $10 \mathrm{~min}$, respectively. The cell walls of flavedo and albedo did not loosen after pressurization. However, after soaking or heating, the middle lamella of albedo separated. Sliced flavedo and homoginized albedo, segment walls and juice sacs of hyuganatsu were soaked in citric acid solution $(\mathrm{pH} 2.7)$, then the marmalades with $50 \%$ sucrose were processed. A great difference in viscosity between HP- and $\mathrm{H}$-marmalade was not found. The amount of naringin was the least in hyuganatsu (hyuganatsu $<$ pummelo $<$ grapefruit). HP-marmalade was evaluated better than H-marmalade by a sensory test. Thus, the total evaluation of hyuganatsu HP-marmalade was highly rated. Hyuganatsu was considered to be more suitable for marmalade because it was more palatable than other marmalades (pummelo and grapefruit).

\section{Acknowledgments}

The authors thank Ms. M. Okamoto for technical assistance. A part of this work was supported by a Grant-in Aid for Young Scientists (B) from the Ministry of Education, Science, Sports and Culture in Japan.

\section{References}

[1] H.S. Choi, M. Sawamura, Volatile flavor components of ripe and overripe ki-mikans (Citrus flaviculpus Hort. ex Tanaka) in composition with hyuganatsu (Citrus tamurana Hort. ex Tanaka), Biosci. Biotechnol. Biochem. 65 (2001) 48-55.

[2] R. Hayashi, Use of High Pressure in Food, San'ei Press, Kyoto, Japan, 1989, pp. 1-30.

[3] Y. Hori, K. Kimura, M. Ida, Y. Yoshida, K. Ohki, Jam preparation by pressurization, Journal of Japanese Society for Bioscience, Biotechnology and Agrochemistry 65 (1991) 975-980. (in Japanese)

[4] Y. Hori, K. Kimura, M. Ida, High pressure-induced jam, Japanese Patent Publication, 1991-219844, 1991, 227. (in Japanese)

[5] M. Fuchigami, K. Okamoto, Fractionation of pectic substances in several vegetables by successive extraction with dilute hydrochloric acid and acetic buffer solutions, J. Jap. Soc. Nutri. Food Sci. 37 (1984) 57-64. (in Japanese)

[6] M. Fuchigami, Relationship between pectic compositions 
and the softening of the texture of Japanese radish roots during cooking, J. Food Sci. 52 (1987) 1317-1320.

[7] M. Fuchigami, Difference between bamboo shoots and vegetables in thermal disintegration of tissues and polysaccharides fractionated by successive extraction, J. Food Sci. 55 (1990) 739-745.

[8] H. Kuwada, Y. Jibu, K. Yasukawa, S. Makio, A. Teramoto, M. Fuchigami, High-pressure-induced yuzu marmalade, in: Gums and Stabilisers for the Food Industry 14, P.A. Williams, G.O. Phillips (Eds.), RSC Publishing, Cambridge, 2008, pp. 518-522.

[9] H. Kuwada, Y. Jibu, A. Teramoto, M. Fuchigami, The quality of high-pressure-induced and heat-induced yuzu marmalade, High Pres. Res. 30 (2010) 547-554.

[10] H. Kuwada, Y. Jibu, A. Teramoto, M. Fuchigami, Changes in pectin, texture and structure of citrus yuzu during soaking in citric acid, heating or pressurization, J. Cookery Sci. Jpn. 45 (2012) 181-188.

[11] Z.I. Kertesz, The Pectic Substances, Interscience Publishers, New York, 1951.

[12] M. Dubois, K.A. Gilles, J.K. Hamilton, P.A. Rebers, F. Smith, Colorimetric method for determination of sugars and related substances, Anal. Chem. 25 (1956) 350-356.

[13] F.A. Betteheim, C. Sterling, Factors associated with potato tuber. II. Pectic substances, Food Res. 20 (1955) 118-129.

[14] H. Miura, T. Mizuta, Effects of gamma radiation on the pectic constituents of Citrus unshu, J. Japan. Soc. Hort. Sci. 31 (1961) 17-22. (in Japanese)

[15] J.T. Galumbos, The reaction of carbazole with carbohydrate: I. Effect of borate and sulfamate on the carbazole color of sugars, Anal. Chem. 19 (1969) 119-132.

[16] T. Iwata, K. Ogata, Bitterness increase due to freezing in natsudaidai (Citrus natsudaidai Hayata) fruits, J. Japan. Soc. Hort. Sci. 45 (1976) 187-191. (in Japanese)

[17] P. Albersheim, H. Neukom, H. Deuel, Splitting of pectic chain molecules in neutral solutions, Arch. Biochem. Biophys. 90 (1960) 46-51.

[18] H. Neukom, H. Deuel, About the decomposition of pectic substance by alkaline reaction, Beiheft Zeitschr. Schweiz Forstv. 30 (1960) 223-235. (in German)

[19] M. Fuchigami, Effect of $\mathrm{pH}$ on the maceration of vegetables, J. Jap. Soc. Nutri. Food Sci. 36 (1983) 219-224. (in Japanese)

[20] M. Fuchigami, Effect of $\mathrm{pH}$ on the thermal degradation of pectic substances, J. Jap. Soc. Nutri. Food Sci. 36 (1983) 294-298. (in Japanese)

[21] M. Fuchigami, A. Teramoto, Y. Jibu, K. Yasukawa, H. Kuwada, N. Yokohata, et al., Changes in polysaccharides and histological structure of the cell wall of "hakuto" peach fruit during maturation, J. Cookery Sci. Jpn. 42 (2009) 9-16. (in Japanese) 